\title{
Affective Profiles of Year 9/10 Australian and South East Asian Students in Science and Science Education
}

\author{
Wan $\mathrm{Ng}^{1 *}$ \\ ${ }^{1}$ University of Technology Sydney, AUSTRALIA
}

Received 5 June 2019 - Revised 11 July 2019 - Accepted 18 July 2019

\begin{abstract}
While there are research studies into students' affective perspectives revolving around science and science education over the last five decades, there are few studies on students' attitudes and beliefs in these areas in developing countries in South East Asia, particularly those that do not participate in international assessment programs. This quantitative study investigated the affective profiles of Year 9/10 students in science/science learning from seven South East Asian countries and Australia to understand the similarities and differences in students' attitudes and the implications in advancing the STEM education agenda in these countries. Comparative studies perform several important functions that are closely interlinked and this study heightens our awareness of the impact of systems and cultures on students' emotional views in the areas of science/science education, allowing country coordinators and policy makers to compare and review teaching practices to enhance student engagement and performance. The implications of the study are discussed.
\end{abstract}

Keywords: attitudes and beliefs, science and science learning, South-East Asian countries and Australia, Year 9 and 10 students

\section{INTRODUCTION}

It is widely accepted, on a global scale, that science, technology, engineering and mathematics (STEM) education as well as its research and development contribute significantly to a nation's productivity and wealth, economic competitiveness and social wellbeing. Freeman, Marginson and Tytler (2015) indicated that contemporary nations with economies that are robust are also strong in STEM. The importance of STEM education has been argued around two strands: the (i) political/business articulation of an urgency that the workforce needs STEM skills, estimating that these skills are required for $75 \%$ of the fastest-growing occupations in the growth of a different economy that we are now witnessing (Becker \& Park, 2011) and (ii) educational argument that the benefits of STEM skills are transferable to other non-STEM related careers and civic participation in society (Education Council, 2018). STEM policy responses have focused largely on school education that include participation and performance in STEM disciplines, curriculum, pedagogy as well as local and international assessment but less so on tertiary or vocational education and training (VET) levels of participation and performance (Freeman, 2014). At the school level, STEM education is mainly focused on science and mathematics education, although some nations' curriculum are beginning to include engineering and computer science education, for example the Australian and UK syllabuses.

Science and mathematics are base disciplines where conceptual knowledge in these areas are essential for engineering and technology discipline learning. Internationally, there is interest amongst many countries to assess their students' performance in school science and mathematics through programs such as the Programme for International Student Assessment (PISA) and Trends in International Mathematics and Science Study (TIMSS). These cognitive assessments rank countries according to the students' performance and governments use these rankings to compare their students' scientific and mathematical literacy not only against other countries but against itself from cycle to cycle of assessments. A drop in ranking from one cycle of testing to the next may send off alarm

(C) 2020 by the authors; licensee Modestum Ltd., UK. This article is an open access article distributed under the terms and conditions of the Creative Commons Attribution License (http://creativecommons.org/licenses/by/4.0/). Wan.Ng@uts.edu.au (*Correspondence) 


\section{Contribution of this paper to the literature}

- There are few studies on students' attitudes/beliefs in science/science learning in developing countries in South East Asia, particularly those that do not participate in international assessment programs.

- This quantitative, comparative study investigated the affective profiles of Year $9 / 10$ students in science/science learning from seven SE Asian countries and Australia to understand the similarities and differences in students' attitudes/beliefs and the implications in advancing the STEM education agenda in these countries.

- The study enhances our awareness of the impact of systems and cultures on students' emotional views in science/science learning, allowing for review of pedagogy to enhance student engagement and performance.

and governments would take urgent steps to modify policies to re-engage students in learning these subjects and to adopt more positive attitudes towards these subjects in order to improve the rankings in the next cycle.

It is well accepted amongst motivation theorists that students' positive attitudes towards learning and positive self-perceptions of subject capability influence motivation that in turn leads to improved performance in academic achievements (Marsh, Trautwein, Lüdtke, Köller \& Baumert, 2005; Shen \& Tam, 2008). However, the aim of governments in ensuring a scientifically literate citizenship is not only about academic achievements that prepare students for future STEM careers, but to be able to engage all students in developing scientific literacy skills and knowledge to become informed, reflective and critical thinkers who are empowered to make decisions in many aspects of life that is largely influenced by science and technology. To achieve both these aims, studies into students' affective domains of science and science learning are important if we are to engage all students to be scientifically literate.

\section{AFFECTIVE COMPONENT OF ATTITUDE TOWARDS SCIENCE AND SCIENCE LEARNING}

Osborne, Simon and Collins (2003) stated the affective component of attitudes towards science as "the feelings, beliefs and values held about an object that may be the enterprise of science, school science, the impact of science on society or scientists themselves" (p, 1053). Research into the attitudes of students towards science and science education has span more than 50 years. These studies are important, especially against a backdrop of declining student interest in science and consequently enrolment in science subjects that impact the supply of professionals in this field in many countries that include Australia, Canada, India, Japan, USA as well as a number of European countries (Awan, Sarwar \& Noreen, 2011; Lyons, 2006). For example in the 1960's there was a perceived "Swing from Science (Butcher, 1969; McPherson, 1969) in the UK that resulted in a government inquiry into falling enrolments in senior science. In Australia, studies have found that between 1971 and 2007, there was a decline in participation in Year 12 science subjects which became a cause for concern that stimulated further investigation of student attitudes to science (Ainley, Kos \& Nicholas, 2008; Cory, 2011; Goodrum, Druhan \& Abbs, 2012; Lyons \& Quinn, 2010). Japan experienced 'PISA shock' in the 2003 PISA performance which saw their formerly high science and mathematics performance declined, and educational authorities putting in place a series of curriculum reforms aimed at lifting the interest and performance of their students in future international testings (Freeman, 2014). By giving students a voice in expressing their feelings and beliefs towards science/science learning, teachers and teacher educators are better informed on how practices could be better aligned with their students' thinking, hence leading to better learning outcomes. This has implications on pedagogy and curriculum development.

\section{FINDINGS IN STUDIES OF STUDENT ATTITUDES TOWARDS SCIENCE AND SCIENCE EDUCATION}

Research into students' affective perspectives revolving around science, scientists and science learning over the last five decades has identified common themes, some of which have held steadfast over time. For example, numerous studies found that students in general display positive attitudes towards science and the contribution of science to society, with male students being more positive than female students (Ato \& Wilkinson, 1983; Banu, 1986; Breakwell \& Beardsell, 1992; Gardner, 1974; Goodrum, Hackling, \& Rennie, 2001; Haladyna \& Thomas, 1979; Johnson, 1981; Jones, Howe \& Rua, 2000; Lowery, Bowyer, \& Padilla, 1980; Menis, 1983; Meyer, 1963; Schibeci \& Riley, 1986; Schreiner \& Sjøberg, 2004; Simpson \& Oliver, 1985; Wooley, 1978).

Science is not usually rated as a favourite subject of school students, for example Powell (1962) found science was ranked sixth of ten subjects by high school students. Jenkins and Nelson (2005) found that only $11 \%$ of $14-15$ 
year old English students liked school science better than other subjects. Similar figures were found in studies for Australian students and elsewhere (Tytler, 2007).

With respect to attitudes towards science career, studies have shown that school students viewed science careers negatively (Jenkins \& Nelson, 2005; Mead \& Métraux, 1957; Silver \& Rushton, 2008). They also viewed scientists negatively (Brush, 1979; Matthews \& Davies, 1999) with fewer girls than boys wanting to become scientists (Sjøberg \& Schreiner, 2010).

In their study of students' progression through school, Barmby, Kind and Jones (2008) found that the as students progressed through school, the 'learning science' factor became a greater influence on attitudes towards future participation in science. The pedagogical practice of teachers was found to be a major influence on high school students' attitudes towards science and science learning (Ebenezer \& Zoller, 1993; Logan \& Skamp, 2013) as well as the maintenance of personal interest (Krapp \& Prenzel, 2011).

Potvin and Hasni (2014) found in their systematic review of 12 years of educational research on interest and attitudes towards science and technology that the vast majority of studies originated from Anglo and European countries, with some studies of high performing Asian countries in international assessment program such as PISA and TIMSS. Some studies that compared attitudes of students from developed and developing countries have been done that showed a common pattern. Researchers in the ROSE project found that the levels of interest in science from students in developing countries such as Uganda, Bangladesh, Philippines and India to be much higher than those from economically developed countries such as Norway, Denmark, UK and Japan (Schreiner \& Sjoberg 2004; Sjoberg \& Schreiner, 2010). Other researchers (Awan et al., 2011; Freeman, 2014) also reported similar findings.

There are few studies on the affective attitudes in science and science education in developing countries in South East Asia, particularly those that did not participate in international assessment programs. Working collaboratively with the South East Asian Ministers of Education Organisation (SEAMEO) through their Regional Centre for Education in Science and Mathematics, this study investigated the attitudes towards science/science learning of Year 9 and 10 students from seven South East Asian countries and Australia to understand the similarities and differences in students' attitudes and the implications in advancing the STEM education agenda in these countries. The seven SE Asian countries that participated in the research were Brunei, Indonesia, Malaysia, Myanmar, Philippines, Thailand and Vietnam. The research questions for the study are: What are the affective profiles (i.e. attitudinal commonalities and differences) of students towards science and science education in participating developing countries in SE Asia? How do these profiles compare with students from a developed country such as Australia? What are the gender differences in attitudes towards the factors investigated? What are the limitations and implications of the study for Science/STEM education?

\section{SIGNIFICANCE OF THE STUDY}

Esser and Vliegenthart (2017) asserted that comparative studies perform several important functions that are closely interlinked: (i) enhancing understanding of one's own society against those of other systems (ii) heightening awareness of other systems, cultures and pattern of thinking/acting (iii) allowing for the testing and evaluation of certain phenomena and contributing to the development of universally applicable theory i.e. generalisation (iv) preventing over-generalisation of researchers based on own idiosynchratic experiences i.e. relativisation and (v) accessing a wide range of alternatives to problem solutions that could facilitate the solving of similar dilemmas at home. This study will enhance our understanding of how students from several Asia-Pacific countries view science/science learning and elicit similarities and differences in those views between countries. The study also heightens our awareness of the impact of systems and cultures on students' emotional views in the area of science education and where appropriate, allows country coordinators and policy makers to compare and review teaching practices to enhance student engagement and performance. For example, Vietnam ranked eighth internationally in the 2015 PISA assessment and is the highest performing country amongst the eight countries in this study. The study's results on Vietnamese students' affective attitudes could inform us of any relationship between attitudes, performance, the science curriculum and government educational policies.

\section{RESEARCH METHOD}

Participants in the study were Year 9/10 students from Australia, Brunei, Indonesia, Malaysia, Myanmar, Philippines, Thailand and Vietnam. Ethics approval and consent from respective Ministers of Education were obtained prior to administrating the research questionnaire to the students by coordinators of respective countries. The questionnaire was translated into the respective country's language and was hosted online on SurveyMonkey. The delegation of research information and survey links to the participating SE Asian countries was coordinated by a staff from SEAMEO's Regional Centre for Education in Science and Mathematics. 
The questionnaire consisted of a set of 4 -point Likert-scale (strongly agree $=4$ to strongly disagree $=1$ ) statements that were grouped in categories to elicit responses to the following factors:

1. Relevance of science

2. Science outside school

3. Teaching and learning science

4. How scientists work

5. Interest in science

6. Self-efficacy in science

7. Future participation in science

The items for the questionnaire were obtained and adapted from other established surveys such as PISA 2006, the Student Understanding of Science and Scientific Inquiry instrument (Liang et al., 2006) and a validated attitude scale (Kind, Jones, \& Barmby, 2007). The questionnaire was validated by teachers of participating schools in Australia and country coordinators of participating SE Asian countries. Feedback obtained was embraced to improve the questionnaire. The survey links were emailed to the project coordinators who forwarded them to the Year 9 and 10 teachers in participating schools. Students completed the questionnaire in class time.

Country coordinators were asked to respond to an open questionnaire that asked for their views to the open questions that sought their general perceptions of what their students valued in science learning, the students selfconcept in science, the pedagogical strategies used in science teaching, the common issues encountered by their students learning science and by their teachers teaching science.

\section{Data Analysis}

Quantitative data was analysed using the SPSS statistical package. There was a rather wide range of responses obtained from the participating countries. For countries with more than 1000 responses, a random selection of 1000 valid responses was conducted on SPSS. The total number of valid responses analysed for each country is shown in Table 1. Means and standard deviations were obtained for each item in each category for each country. For comparison purposes, mean category values for individual categories were obtained i.e. the mean of all the item means in each category. To detect gender differences in the responses of each country, t-tests were conducted. Reliability of the instrument was obtained by calculating the Cronbach alpha values that measured the internal consistency of the items. Negative items were reverse coded prior to calculating Cronbach alpha values. Each component was considered as acceptable if Cronbach's alpha exceeded 60.

Open survey responses were qualitatively analysed and grouped according to emerging themes or categories.

\section{RESULTS AND DISCUSSION}

\section{Demographics of Participating Schools and Students}

As shown in Table 1, a total of 8 Asia-Pacific countries participated in the research, with 7 of them from the South-East Asia region, these being Brunei, Indonesia, Malaysia, Myanmar, Philippines, Thailand and Vietnam. The eighth country was Australia. The number of schools that participated in the research ranged from 5 (Indonesia) to 15 (Australia and Thailand). The types of schools from the countries were mixed but they were mainly government schools from urban areas and very few from private schools. The socio-economic status (SES) of these schools is also mixed with Malaysia opting for schools that all had low SES while all of Thailand's participating schools were from high SES background. The SES of the schools in the other countries were from a mix of SES backgrounds, for example, schools from Brunei and Indonesia were mainly from medium levels of SES while the schools from Myanmar were a combination of 4 high, 3 medium and one low SES background. Australian schools that participated were from high and low SES background ( 9 high SES and 6 low SES schools) but the academic performance of these schools were more evenly distributed with 6 of them being highly academic, four medium and five were low academically. For Indonesia, even though the SES of the schools were medium and low, the academic performance, as indicated by the country project coordinator, were mostly high (4 schools) and medium (1 school). Similarly, for the Philippino schools participating in the research, there were 14 government, urban schools and 6 government, rural schools. All 20 schools were classified as medium SES schools, but 12 of them were academically high performing schools and all were urban schools. The 6 rural schools demonstrated medium levels of academic performance. Hence the schools' socio-economic status do not necessarily reflect the academic performance of the schools. 
Table 1. Demographics of participants from the participating countries

\begin{tabular}{|c|c|c|c|c|c|c|c|c|}
\hline \multirow{2}{*}{ Country } & \multirow{2}{*}{$\begin{array}{l}\text { Total No. } \\
\text { of Schools } \\
\text { (Students) } \\
\text { Invited }\end{array}$} & \multirow{2}{*}{$\begin{array}{c}\text { Type of School: } \\
\text { Government or } \\
\text { Private, Urban or } \\
\text { Rural }\end{array}$} & \multirow{2}{*}{$\begin{array}{l}\text { SES of School: } \\
\text { (High, Medium } \\
\quad \text { or Low) }\end{array}$} & \multirow{2}{*}{$\begin{array}{c}\text { Academic } \\
\text { Performance of } \\
\text { School at Year } 12 \\
\text { (High, Medium, Low)* }\end{array}$} & \multirow{2}{*}{$\begin{array}{l}\text { Total No. of } \\
\text { Responses } \\
\text { to Survey }\end{array}$} & \multicolumn{3}{|c|}{$\begin{array}{c}\text { No. of } \underline{\text { Valid Responses }} \\
\text { for Analysis }\end{array}$} \\
\hline & & & & & & Male & Female & Total \\
\hline Australia & 15 & $\begin{array}{c}10 \text { Govt, Urban } \\
3 \text { Govt, Rural } \\
2 \text { Private, Urban } \\
\end{array}$ & $\begin{array}{l}9 \text { High } \\
6 \text { Low }\end{array}$ & $\begin{array}{c}6 \text { High } \\
4 \text { Medium } \\
5 \text { Low } \\
\end{array}$ & 1344 & 369 & 631 & $\begin{array}{c}1000 \\
\left(1318^{\star \star}\right)\end{array}$ \\
\hline Brunei & 12 & $\begin{array}{l}11 \text { Govt, Urban } \\
1 \text { Private, Urban }\end{array}$ & $\begin{array}{c}1 \text { High } \\
11 \text { Medium }\end{array}$ & N/A & 1151 & 349 & 393 & 742 \\
\hline Indonesia & 5 & $\begin{array}{l}3 \text { Govt, Urban } \\
2 \text { Govt, Rural }\end{array}$ & $\begin{array}{l}4 \text { Medium } \\
1 \text { Low }\end{array}$ & $\begin{array}{c}4 \text { High } \\
1 \text { Medium }\end{array}$ & 2655 & 414 & 586 & $\begin{array}{c}1000 \\
(1800 * \star \\
\end{array}$ \\
\hline Malaysia & 10 & $\begin{array}{c}\text { All Govt } \\
\text { Urban/ Rural data } \\
\text { N/A }\end{array}$ & All low & All low & 490 & 156 & 191 & 347 \\
\hline Myanmar & 9 & $\begin{array}{c}6 \text { Govt, Urban } \\
1 \text { Govt, Rural } \\
1 \text { Private, Urban }\end{array}$ & $\begin{array}{c}4 \text { High } \\
3 \text { Medium } \\
1 \text { Low } \\
\end{array}$ & $\begin{array}{c}4 \text { High } \\
3 \text { Medium } \\
1 \text { Low } \\
\end{array}$ & 1050 & 290 & 473 & 763 \\
\hline Philippines & 20 & $\begin{array}{c}14 \text { Govt, Urban } \\
6 \text { Govt, Rural }\end{array}$ & All Medium & $\begin{array}{c}12 \text { High } \\
8 \text { Medium }\end{array}$ & 1285 & 329 & 586 & 915 \\
\hline Thailand & 15 & $\begin{array}{l}9 \text { Govt, Urban } \\
1 \text { Private, Urban } \\
1 \text { Govt, Rural } \\
4 \text { Private, Rural }\end{array}$ & All high & All high & 759 & 246 & 423 & 669 \\
\hline Vietnam & Multiple & Multiple & Multiple & Multiple & 9160 & 420 & 580 & $\begin{array}{c}1000 \\
\left(5900^{\star *}\right)\end{array}$ \\
\hline
\end{tabular}

*High $=80 \%$ or more of the students enter universities or a tertiary institution; Medium $=50 \%$ or more of the students enter universities or a tertiary institution; Low $=$ less than $50 \%$ of the students enter universities or a tertiary institution

**represents the total number of valid responses obtained from which 1000 responses were randomly selected for comparison purposes.

Table 1 also shows the total number of responses obtained from each country and the number of responses that were valid. For countries that had more than 1000 valid responses (Australia had 1318; Indonesia had 1800; Vietnam had 5900), a selection of 1000 responses in SPSS as a maximum was conducted for comparison purposes with countries less than 1000 responses. The number of male and female students' data that were used for the analysis are also indicated in Table 1. There appears to be a general trend of more female students responding to the questionnaire that was hosted on Survey Monkey than male students. A possible reason is that female students were more willing to voluntarily complete the online questionnaire than male students.

\section{Country Coordinators' Open Responses}

Five coordinators from Australia, Brunei, Malaysia, Myanmar and Philippines returned responses to questions as indicated in the Methods section. Where appropriate, responses are quoted to support and/or provide further insights to the students' responses in the sections below.

\section{PERCEPTIONS OF YEAR 9 AND 10 STUDENTS}

Responses were sought from the students on their perceptions of a range of science-related factors. These factors were itemised in seven categories: relevance of science, science outside school, teaching and learning science, how scientists work, self-efficacy in science, interest in science and their future participation in science. Table 2 shows the results of the mean values and Cronbach's a for each category (called category means from here on) for the participating countries. The presentation and discussion of the results will be based largely on category means but where appropriate, mean values of selected items that make up the categories will be shown and discussed to obtain a deeper insight into the category mean values presented in Table 2. A mean of 2.5 (out of a maximum of 4 ) is considered neutral as it indicates about 50\% agreement (agree or strongly agree) with the item statements or categories investigated. Means greater than 2.5 are considered positive and means less than 2.5 as negative. 
Table 2. Category mean values and Cronbach's $\alpha$ for each category

\begin{tabular}{|c|c|c|c|c|c|c|c|c|c|c|c|c|c|c|c|c|}
\hline $\begin{array}{l}\text { Category } \\
\text { (number of } \\
\text { items) }\end{array}$ & $\frac{\frac{\pi}{\bar{T}}}{\frac{\pi}{\frac{\pi}{2}}}$ & 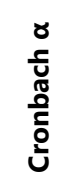 & & 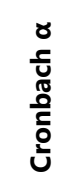 & $\begin{array}{l}\frac{\pi}{y} \\
\stackrel{0}{0} \\
\underline{0} \\
\underline{\underline{c}}\end{array}$ & 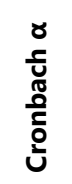 & $\frac{\frac{\pi}{\sqrt{n}}}{\frac{\pi}{\pi}}$ & 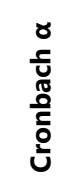 & $\sum_{\substack{\pi \\
\frac{\pi}{\pi}}}^{\frac{1}{\pi}}$ & 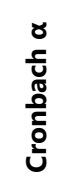 & 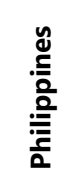 & 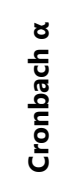 & $\begin{array}{l}\text { D } \\
\frac{\pi}{\pi} \\
\frac{\pi}{\pi} \\
\text { f }\end{array}$ & 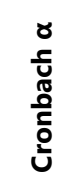 & 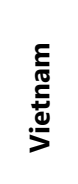 & 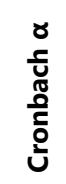 \\
\hline $\begin{array}{l}\text { Relevance of } \\
\text { science (7) }\end{array}$ & 2.92 & .865 & 3.22 & .789 & 3.17 & .810 & 3.28 & .798 & 3.21 & .796 & 3.43 & .798 & 3.36 & .810 & 3.36 & .897 \\
\hline $\begin{array}{l}\text { Science } \\
\text { outside } \\
\text { School (6) }\end{array}$ & 2.29 & .873 & 2.88 & .727 & 2.78 & .757 & 3.06 & .768 & 3.15 & .752 & 3.16 & .790 & 3.08 & .806 & 3.16 & .855 \\
\hline $\begin{array}{l}\text { Teaching and } \\
\text { learning } \\
\text { science (11) }\end{array}$ & 2.41 & .831 & 3.07 & .776 & 3.12 & .790 & 3.20 & .833 & 2.96 & .815 & 3.24 & .836 & 3.12 & .826 & 3.26 & .890 \\
\hline $\begin{array}{l}\text { How scientists } \\
\text { work (6) }\end{array}$ & 2.81 & .634 & 3.05 & .565 & 2.98 & .443 & 3.09 & .645 & 3.12 & .575 & 3.20 & .556 & 3.16 & .635 & 3.25 & .783 \\
\hline $\begin{array}{l}\text { Self-efficacy } \\
\text { in science (2) }\end{array}$ & 2.54 & .751 & 2.37 & .561 & 2.43 & .699 & 2.48 & .455 & 2.68 & .320 & 2.65 & .661 & 2.53 & .495 & 2.44 & .086 \\
\hline $\begin{array}{l}\text { Interest in } \\
\text { science (4) }\end{array}$ & 2.70 & .855 & 3.07 & .722 & 2.97 & .721 & 3.09 & .633 & 3.17 & .554 & 3.27 & .698 & 3.04 & .719 & 3.06 & .619 \\
\hline $\begin{array}{l}\text { Future } \\
\text { participation } \\
\text { in science (3) }\end{array}$ & 2.53 & .919 & 3.13 & .834 & 3.15 & .875 & 3.20 & .831 & 3.12 & .752 & 3.32 & .806 & 3.20 & .828 & 3.21 & .840 \\
\hline
\end{tabular}

As shown in Table 2, the Cronbach's a values for the vast majority of categories for the eight countries are around .6 and above, indicating good reliability of the responses by the students. The exception is the value for Vietnam's self-efficacy which is very low for unknown reasons. For ease of comparisons between the countries, the category means are visually presented in Figures 1(a)-(g).

\section{RELEVANCE OF SCIENCE}

This category examines the students' valuing of science and its impact on society as well as the personal benefits it brings to them as future citizens of a nation. Figure 1(a) shows that the Year 9/10 students from all countries value science and its relevance, as indicated by the high category means of 2.92 and above. The responses of students from the SE Asian countries were more positive than their Australian counterparts, with mean values well over 3.0 compared with the Australian students' category mean of 2.92. As shown in Table 3 of item means for this category, the less positive responses from the Australian students are due largely to their lowered perception of the relevance of science at a personal level. For these students, they rated items associating science benefits to society more positively than items relating to personal benefits of science, these being 'I will use science in many ways when I am an adult' (item mean value=2.74), 'Science is very relevant to me' (item mean value=2.72) and 'Reasoning skills that are taught in science classes can be helpful to me in my everyday life' (item mean=2.77). Interestingly, these items relating to personal benefits of science were also the least positively viewed by students in SE Asian countries, in particular the 'Science is very relevant to me' item. The all-country mean score (see last column of Table 3) that provides the average of the means of all the countries for a particular item, is the lowest for the 'Science is very relevant to me' item (all-country mean of 3.08).

Responses of country coordinators provide better insights into the values they perceive that their students place on science learning. Four out of the five country coordinators who returned responses to the open questions, indicated science is relevant to students in helping them get into the science stream in Year 9 and science provide better opportunities for a better education and to secure a better career. Three of the coordinators indicated that curiosity and enjoyment in science, as well as understanding the natural world were what their students value in science. Examples of quotes are:

Our students see it as an important subject for streaming to Year 9. They also believe Science as one of the most important subjects to secure a brighter future career (Brunei coordinator)

Students from both the regular program and the science high schools agree that learning science is very important in explaining phenomena observable in the natural world. It prevents learners to be swayed into superstition and fake news. (Philippines coordinator) 


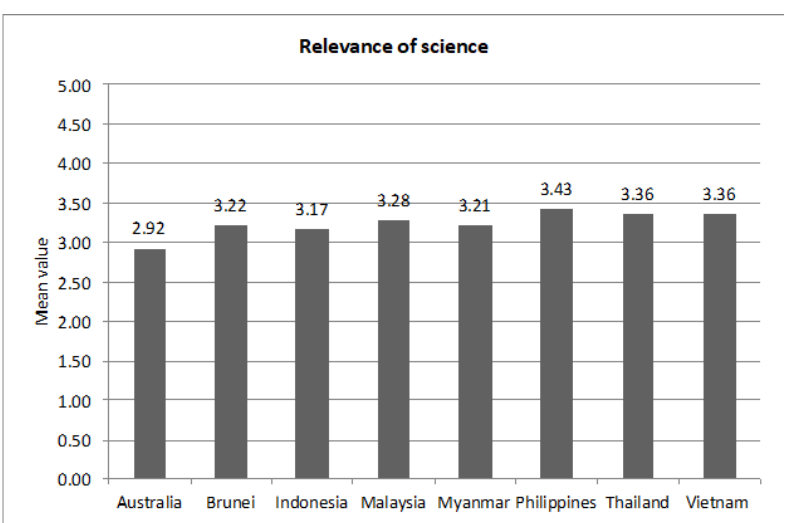

(a) Category means for 'Relevance of Science'

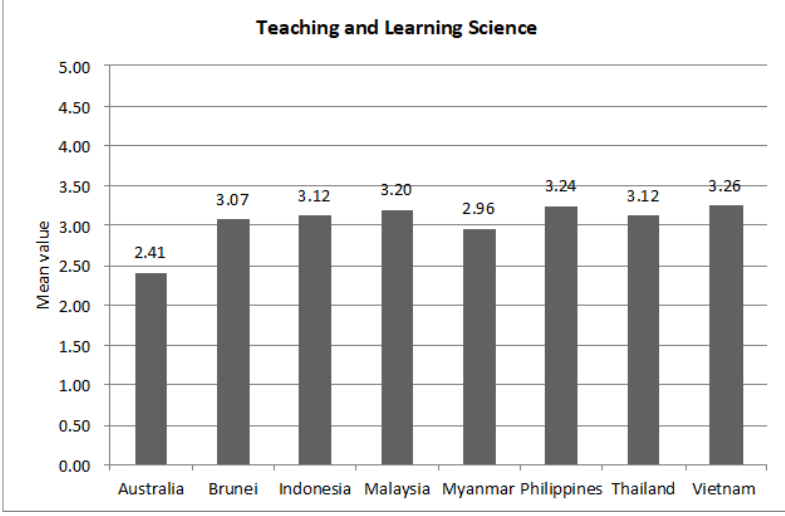

(c) Category means for 'Teaching and learning Science'

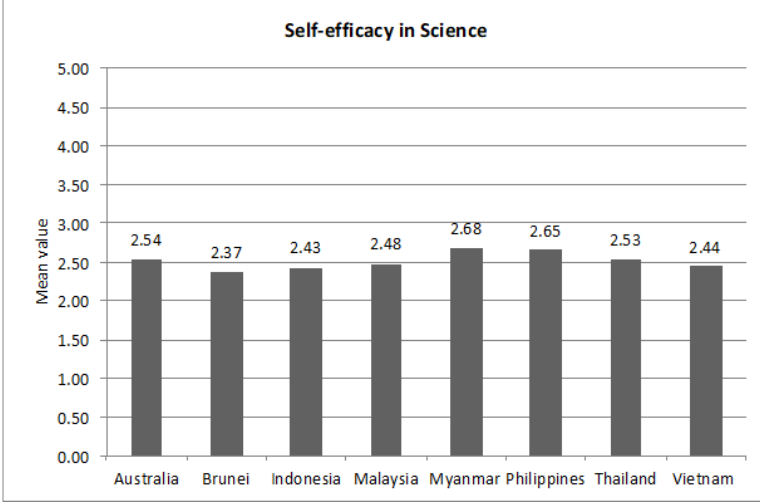

(e) Category means for 'Self-efficacy in science'

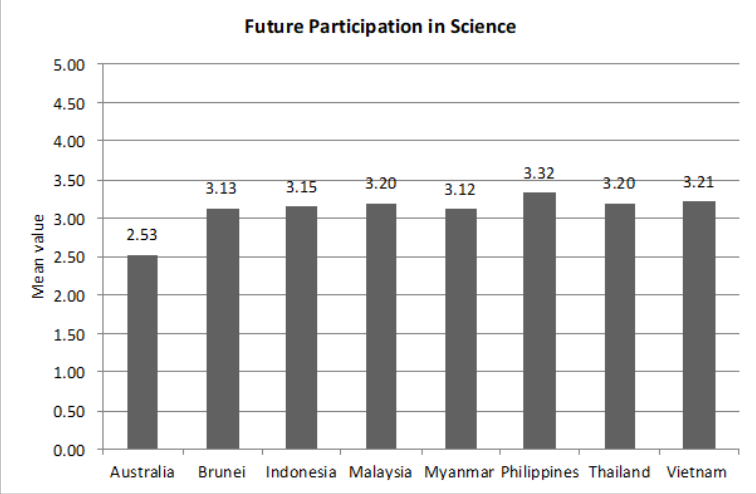

(g) Category means for 'Future participation in science'

Figure 1 (a)-(g). Category means visually displayed

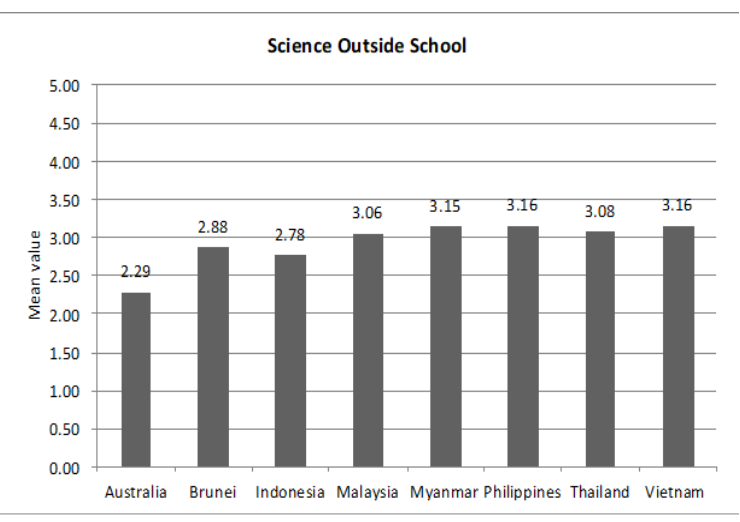

(b) Category means for 'Science outside school'

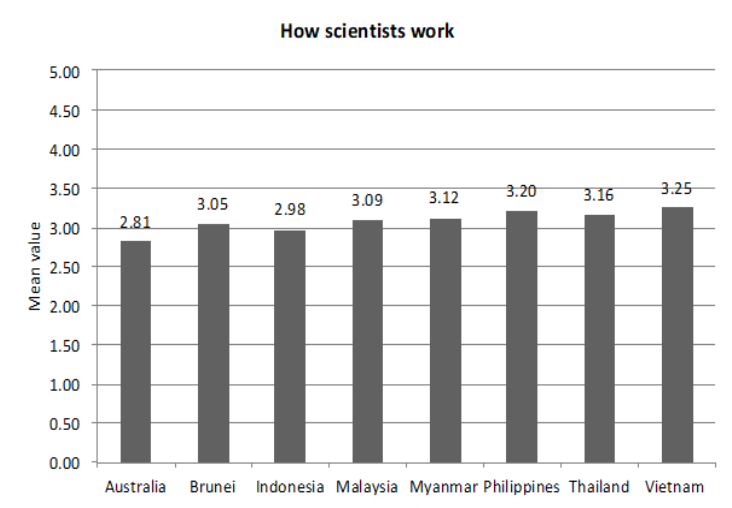

(d) Category means for 'How scientists work'

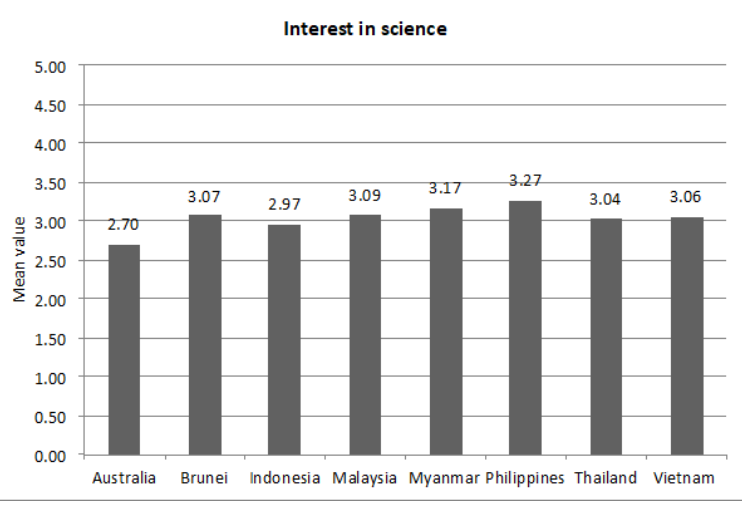

(f) Category means for 'Interest in science' 
Table 3. 'Relevance of Science' category: Mean values of items, category means and all-country means

Relevance of Science

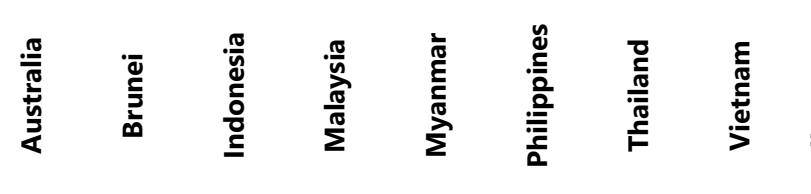

\begin{tabular}{|c|c|c|c|c|c|c|c|c|c|}
\hline $\begin{array}{l}\text { Advances in science and technology usually improve } \\
\text { people's living standards. }\end{array}$ & 3.23 & 3.36 & 3.37 & 3.41 & 3.48 & 3.58 & 3.54 & 3.47 & 3.43 \\
\hline $\begin{array}{l}\text { Advances in science and technology usually help } \\
\text { improve the economy. }\end{array}$ & 3.08 & 3.32 & 3.25 & 3.39 & 3.34 & 3.56 & 3.48 & 3.45 & 3.36 \\
\hline I will use science in many ways when I am an adult. & 2.74 & 3.11 & 3.14 & 3.21 & 3.11 & 3.32 & 3.23 & 3.33 & 3.15 \\
\hline Science is very relevant to me. & 2.72 & 3.06 & 2.99 & 3.25 & 2.98 & 3.32 & 3.25 & 3.10 & 3.08 \\
\hline Science helps me understand the things around me. & 3.07 & 3.38 & 3.24 & 3.31 & 3.21 & 3.51 & 3.36 & 3.40 & 3.31 \\
\hline $\begin{array}{l}\text { Advances in science and technology usually bring } \\
\text { social benefits. }\end{array}$ & 2.82 & 3.10 & 3.13 & 3.20 & 3.25 & 3.33 & 3.46 & 3.42 & 3.21 \\
\hline $\begin{array}{l}\text { Reasoning skills that are taught in science classes can } \\
\text { be helpful to me in my everyday life. }\end{array}$ & 2.77 & 3.18 & 3.09 & 3.16 & 3.12 & 3.36 & 3.19 & 3.33 & 3.15 \\
\hline Category mean & 2.92 & 3.22 & 3.17 & 3.28 & 3.21 & 3.43 & 3.36 & 3.36 & \\
\hline
\end{tabular}

Table 4. 'Science Outside School' category: Mean values of items, category means and all-country means

\begin{tabular}{|c|c|c|c|c|c|c|c|c|c|}
\hline Science Outside School & $\frac{. \frac{\pi}{\pi}}{\stackrel{\frac{\pi}{2}}{\frac{\hbar}{2}}}$ & & $\begin{array}{l}\frac{\pi}{y} \\
\stackrel{0}{0} \\
\stackrel{0}{0}\end{array}$ & $\frac{\frac{\pi}{\sqrt{n}}}{\frac{\pi}{\pi}}$ & 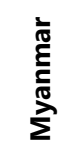 & 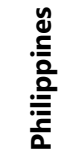 & 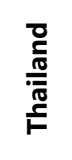 & 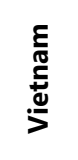 & 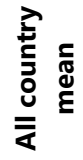 \\
\hline I like watching science programs on TV. & 2.54 & 2.87 & 2.69 & 3.02 & 3.19 & 3.16 & 2.99 & 3.23 & 2.96 \\
\hline I like to visit science centres and science museums. & 2.52 & 3.11 & 2.87 & 3.30 & 3.34 & 3.30 & 3.19 & 3.22 & 3.11 \\
\hline $\begin{array}{l}\text { I would like to do more science activities outside school, } \\
\text { e.g. join a science club. }\end{array}$ & 2.05 & 3.04 & 2.60 & 3.14 & 3.09 & 3.23 & 3.17 & 3.12 & 2.93 \\
\hline I like reading science magazines, books and newspapers. & 2.25 & 2.60 & 2.75 & 2.84 & 3.04 & 3.04 & 2.94 & 3.06 & 2.82 \\
\hline I like to visit web sites to learn about science. & 2.28 & 2.69 & 2.83 & 2.94 & 3.01 & 3.08 & 2.99 & 3.05 & 2.86 \\
\hline $\begin{array}{l}\text { I like using social media to access science-related } \\
\text { information or to keep up-to-date with science e.g. } \\
\text { Facebook, Twitter, Instagram. }\end{array}$ & 2.12 & 2.95 & 2.91 & 3.10 & 3.24 & 3.12 & 3.17 & 3.28 & 2.99 \\
\hline Category mean & 2.29 & 2.88 & 2.78 & 3.06 & 3.15 & 3.16 & 3.08 & 3.16 & \\
\hline
\end{tabular}

\section{SCIENCE OUTSIDE SCHOOL}

From Figure 1(b), the three mean values for this category that are less than 3.0 are Australia (2.29), Brunei (2.88) and Indonesia (2.78), indicating that students from these countries and in particular Australia were less interested in being involved in science outside school hours. Students from the Philippines (mean=3.16), Myanmar $($ mean=3.15) and Vietnam (mean=3.16) were most interested in science outside school. In analysing the mean values of individual items in this category (see Table 4), we see that as a general trend, visiting museums was rated most positively by the students from all the countries, with an all-country mean of 3.11. This is followed by 'I like using social media to access science-related information or to keep up-to-date with science e.g. Facebook, Twitter, Instagram' (mean=2.99) and 'I like watching science programs on television' (mean=2.96). Table 4 also shows the items that are less than 2.5 for the Australian students, these being 'join a science club' (mean=2.05), using social media to access science-related information (mean=2.12), reading science magazines, books and newspapers $($ mean=2.25) and visiting web sites to learn about science (mean=2.28).

\section{TEACHING AND LEARNING SCIENCE}

This category investigated students' perceptions of how science was taught in their classrooms. The items probed for the balance between traditional teaching and learning (textbook and lecture-based; following instructions for experimental work) and independent, inquiry-based learning (e.g. students design investigations, apply concepts to everyday problems, undertake online research and investigations). The category also elicited students' perceptions of how well their teachers taught science. As shown in Figure 1(c), Australian students were the least positive about how science was taught in the classroom, scoring a category mean of 2.41 while the students 
Table 5. 'Teaching and Learning Science' category: Mean values of items, category means and all-country means

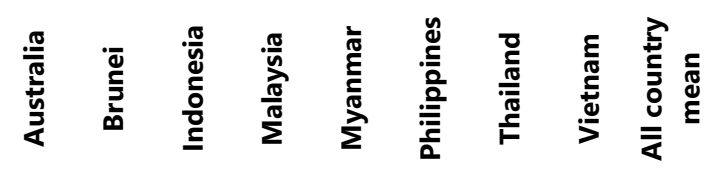

\begin{tabular}{llllllllll}
\hline Students are given opportunities to explain their ideas. & 2.68 & 3.09 & 3.41 & 3.18 & 3.19 & 3.31 & 3.12 & 3.48 & $\mathbf{3 . 1 8}$ \\
\hline $\begin{array}{l}\text { Students spend time in the laboratory doing practical experiments. } \\
\text { Students are required to design how a science question could be }\end{array}$ & 2.11 & 3.04 & 3.22 & 2.44 & 3.06 & 3.23 & 3.21 & $\mathbf{2 . 9 2}$ \\
\hline \begin{tabular}{l} 
investigated in the laboratory. \\
\hline Students are asked to apply a science concept to everyday problems.
\end{tabular} & 2.20 & 2.76 & 2.91 & 2.97 & 2.84 & 3.00 & 3.03 & 3.29 & $\mathbf{2 . 8 8}$ \\
\hline $\begin{array}{l}\text { Students do experiments by following the instructions of the teacher. } \\
2.94\end{array}$ & 3.38 & 3.24 & 3.35 & 3.05 & 3.37 & 3.06 & 3.34 & $\mathbf{3 . 2 2}$ \\
\hline $\begin{array}{l}\text { The teacher clearly explains the relevance of science and technology } \\
\text { concepts to our lives. }\end{array}$ & 2.53 & 3.23 & 3.23 & 3.37 & 3.12 & 3.36 & 3.10 & 3.35 & $\mathbf{3 . 1 6}$ \\
\hline $\begin{array}{l}\text { The teacher tells stories about the lives of scientists and how they } \\
\text { make discoveries. }\end{array}$ & 2.07 & 2.95 & 3.11 & 3.32 & 2.99 & 3.29 & 3.03 & 3.30 & $\mathbf{3 . 0 1}$ \\
\hline $\begin{array}{l}\text { Students research online for information related to the topic being } \\
\text { studied. }\end{array}$ & 2.47 & 3.03 & 3.08 & 3.18 & 3.04 & 3.39 & 3.16 & 3.35 & $\mathbf{3 . 0 9}$ \\
\hline $\begin{array}{l}\text { Students are engaged in investigations using online resources e.g. } \\
\text { virtual laboratory or simulations. }\end{array}$ & 2.07 & 2.77 & 2.92 & 3.05 & 3.04 & 3.10 & 3.13 & 3.27 & $\mathbf{2 . 9 2}$ \\
\hline \begin{tabular}{l} 
Students learn mostly from textbooks and the teacher lectures. \\
\hline Students learn interesting things in science lessons.
\end{tabular} & 2.79 & 3.24 & 3.02 & 3.18 & 3.03 & 3.21 & 3.18 & 2.64 & $\mathbf{3 . 0 4}$ \\
\hline Category mean & $\mathbf{2 . 4 1}$ & $\mathbf{3 . 0 7}$ & $\mathbf{3 . 1 2}$ & $\mathbf{3 . 2 0}$ & $\mathbf{2 . 9 6}$ & $\mathbf{3 . 2 4}$ & $\mathbf{3 . 1 2}$ & $\mathbf{3 . 2 6}$ & \\
\hline
\end{tabular}

from all the participating SE Asian countries viewed the science teaching and their learning much more positively with Vietnamese students being the most positive with a mean value of 3.26 for this category.

\section{Traditional vs Independent, Inquiry-based Learning}

There appears to be a balance in the way science was taught in the countries. The students from all eight countries indicated strong agreement in traditional practices, as shown in the high all-country mean values (see Table 5) of 3.22 for the item 'Students do experiments by following the instructions of the teacher' and 3.04 for the item 'Students learn mostly from textbooks and the teacher lectures'. Across all eight countries, students were a little less positive about the independent, hands-on aspects of science learning with all-country mean scores of 2.88 for 'Students are asked to apply a science concept to everyday problems', 2.91 for 'Students are required to design how a science question could be investigated in the laboratory', 2.92 for 'Students spend time in the laboratory doing practical experiments' and 'Students are engaged in investigations using online resources e.g. virtual laboratory or simulations'. The Australian students were considerably less positive than their SE Asian counterparts scoring less than 2.5 for these four items.

The students' responses largely concorded with what the country coordinators said with respect to the teaching and learning approaches in the science classrooms. All the country coordinators identified a mixture of studentcentred and teacher-centred approaches. Teacher-centred approaches included typical chalk and talk/lecture type teaching and summative assessments. A range of student-centred approaches were indicated by all the country coordinators that included practical activities, discussion method, field trips and approaches that are inquiry-based, discovery-based, multi/interdisciplinary approach and project/problem-based. An example of a quote, from the Myanmar coordinator, is shown below:

In our country, the teacher teaches science to students mostly by using lecture method, discussion method, discovery approaches, interaction approach and doing practical experiments.

\section{Other Aspects of the Science Teachers' Teaching}

Overall, the all-country mean scores in Table 5 indicate that the students from the participating countries, particularly the SE Asian students, were positive about their science teachers teaching in the following areas: 'The teacher clearly explains the relevance of science and technology concepts to our lives' (all-country mean=3.16), 'The teacher tells stories about the lives of scientists and how they make discoveries' (all-country mean=3.01) and 'Students learn interesting things in science lessons' (all-country mean=3.21). Australian students were less positive in their perceptions pertaining to these items than their SE Asian peers, in particular the item about their teachers 
Table 6. 'How Scientists Work' category: Mean values of items, category means and all-country means

How Scientists Work

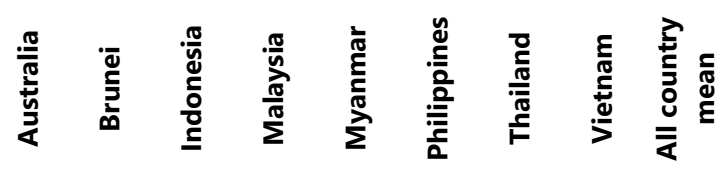

\begin{tabular}{|c|c|c|c|c|c|c|c|c|c|}
\hline $\begin{array}{l}\text { Scientists use their imagination and creativity when they plan } \\
\text { investigations. }\end{array}$ & 2.64 & 3.13 & 3.22 & 3.15 & 3.40 & 3.37 & 3.27 & 3.39 & 3.20 \\
\hline $\begin{array}{l}\text { Scientists use their imagination and creativity when they analyse } \\
\text { and interpret data. }\end{array}$ & 2.43 & 2.96 & 2.94 & 3.12 & 3.22 & 3.13 & 3.09 & 3.25 & 3.02 \\
\hline $\begin{array}{l}\text { Scientists use different types of methods to conduct scientific } \\
\text { investigations. }\end{array}$ & 3.14 & 3.34 & 3.12 & 3.13 & 3.31 & 3.46 & 3.23 & 3.39 & 3.27 \\
\hline All scientists follow the same step-by-step scientific method. & 2.44 & 2.79 & 2.70 & 3.09 & 2.83 & 2.87 & 2.88 & 3.03 & 2.83 \\
\hline $\begin{array}{l}\text { Scientific investigations can be conducted using computer } \\
\text { technology. }\end{array}$ & 3.03 & 3.08 & 3.09 & 3.12 & 3.19 & 3.20 & 3.14 & 3.17 & 3.13 \\
\hline Scientific ideas can be changed. & 3.19 & 2.97 & 2.78 & 2.91 & 2.74 & 3.17 & 3.33 & 3.24 & 3.04 \\
\hline Category mean & 2.81 & 3.05 & 2.98 & 3.09 & 3.12 & 3.20 & 3.16 & 3.25 & \\
\hline
\end{tabular}

telling stories about the lives of scientists that scored only a mean of 2.07. In comparing this category's mean values (see last row in Table 5) between SE Asian students, Myanmar scored the lowest in how its students viewed this category with a mean score of 2.96. The item analysis as shown in Table 5 shows that Myanmar students were less positive for the item 'Students spend time in the laboratory doing practical experiments' (item mean score of 2.44) compared to the other six SE Asian countries' scores of more than 3. The other item that Myanmar students perceived most negatively amongst the SE Asian peers is 'Students are required to design how a science question could be investigated in the laboratory' (item mean $=2.69$ ). Australian students also scored low mean values for these two items, 2.04 and 2.17 respectively. This suggests that the participating students from Myanmar and Australia perceived that opportunities for hands-on learning in science to be less than their counterparts from the other countries.

\section{HOW SCIENTISTS WORK}

Overall, as shown in Table 6, all the participating students from the eight countries seem to view how scientists work positively with category mean scores ranging from 2.81 (Australia) to 3.25 (Vietnam). The general trend of the students' perceptions of how scientists work is that they were more positive about 'Scientists use their imagination and creativity when they plan investigations' (all-country mean=3.20) and less so for 'Scientists use their imagination and creativity when they analyse and interpret data' (all-country mean=3.02). This could be due to the students' perception of the objectivity in analysing and interpreting data where the need to be creative and imaginative is unnecessary. The students also believed strongly that 'Scientists use different types of methods to conduct scientific investigations' (all-country mean=3.27), 'Scientific investigations can be conducted using computer technology' (all-country mean=3.13) and 'Scientific ideas can be changed' (all-country mean=3.03). They were less positive about 'All scientists follow the same step-by-step scientific method' (all-country mean=2.83) which is consistent with the strong belief that scientists use different methods to conduct scientific investigations (all-country mean=3.27).

\section{INTEREST IN SCIENCE}

In this four-item category, students were asked to rate their liking of science in comparison with other subjects, whether they found science was boring, and if they were interested in learning about science and enjoyed gaining new knowledge in science. As shown in Table 7, the general trend expressed by students in all countries is that they were very positive about enjoying acquiring new knowledge in science (all-country mean=3.33) and were interested in learning about science (all-country mean=3.27). They were less positive about liking science better than other school subject (all-country mean=2.64) or finding science not boring (all-country mean=2.94). At the individual country level, Australia was the least positive about being interested in science (category mean=2.70) although they seem to enjoy acquiring new knowledge in science (item mean=3.02). Students from the Philippines and Myanmar appear to be most interested in science with category mean values of 3.27 and 3.17 respectively. 
Table 7. 'Interest in Science' category: Mean values of items, category means and all-country means

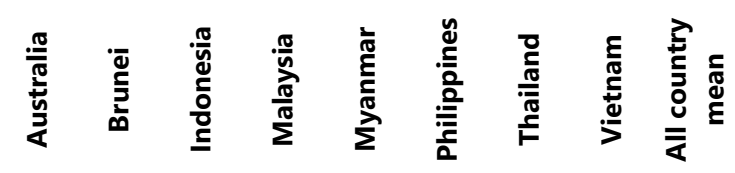

\begin{tabular}{llllllllll}
\hline I like science better than most other subjects at school. & 2.20 & 2.56 & 2.49 & 2.60 & 3.02 & 2.78 & 2.74 & 2.73 & $\mathbf{2 . 6 4}$ \\
\hline Science is boring. (reversed) & 2.63 & 3.13 & 2.88 & 3.01 & 2.98 & 3.25 & 2.80 & 2.85 & $\mathbf{2 . 9 4}$ \\
\hline I enjoy acquiring new knowledge in science. & 3.02 & 3.30 & 3.29 & 3.43 & 3.37 & 3.53 & 3.33 & 3.40 & $\mathbf{3 . 3 3}$ \\
\hline I am interested in learning about science. & 2.96 & 3.28 & 3.21 & 3.31 & 3.32 & 3.51 & 3.28 & 3.26 & $\mathbf{3 . 2 7}$ \\
\hline Category mean & $\mathbf{2 . 7 0}$ & $\mathbf{3 . 0 7}$ & $\mathbf{2 . 9 7}$ & $\mathbf{3 . 0 9}$ & $\mathbf{3 . 1 7}$ & $\mathbf{3 . 2 7}$ & $\mathbf{3 . 0 4}$ & $\mathbf{3 . 0 6}$ & \\
\hline
\end{tabular}

Table 8. 'Self-efficacy in Science' category: Mean values of items, category means and all-country means

\begin{tabular}{|c|c|c|c|c|c|c|c|c|}
\hline 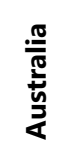 & & 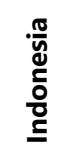 & $\frac{\frac{\pi}{\sqrt{n}}}{\frac{\pi}{\pi}}$ & 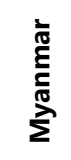 & 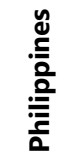 & 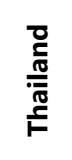 & 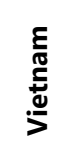 & 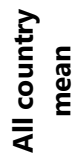 \\
\hline 52 & & 2.56 & 2.63 & 2.82 & 2.81 & 2.77 & 2.70 & 2.66 \\
\hline 55 & 2.24 & 2.30 & 2.33 & 2.54 & 2.49 & 2.29 & 2.18 & 2.37 \\
\hline 54 & 2.37 & 2.43 & 2.48 & 2.68 & 2.65 & 2.53 & 2.44 & \\
\hline
\end{tabular}

\section{SELF-EFFICACY IN SCIENCE}

To probe the self-efficacy of students in science, they were asked if they found science difficult and if they were able to learn science quickly. As shown in Table 8, the general pattern of the students' self-assessment of their selfefficacy in science across the eight countries was rather low with all-country mean of 2.37 for 'I (do not) find science difficult' (item is reverse coded) and all-country mean value of 2.66 for the item 'I learn science quickly'. Similar low category mean values are found for all the participating countries.

The general finding that students across the eight countries find science difficult is supported by the country coordinators' comments about students' self-concept in science. While all the country coordinators acknowledged this aspect of science learning, some indicated that the difficult nature of science did not deter students' interest in the subject, as shown below:

Many students find science difficult and enrolments in science subjects in senior secondary schools have generally fallen. But they like the hands-on activities in science. (Australian coordinator)

A majority of our students find difficulty in learning Science. They have a hard time in understanding scientific terms. This leads them into believing that Science is a difficult subject to excel. Surprisingly though, despite their difficulty in coping with the subject, most students find science as an interesting subject and are fascinated by the experiments done at school. (Brunei coordinator)

Students show their self-concept that science learning is difficult to them but science is the most popular among Myanmar students. Majority of students choose science subjects as a foundation course for their career. (Myanmar coordinator)

The reasons that country coordinators provided with respect to students' difficulties in science learning include the abstract nature of science, language difficulties with science concepts, lack of mathematical ability to handle mathematical-oriented science concept, lack of laboratory equipment, computers and other learning resources including the limited supply of water and electricity in some parts of the country. Examples of some quotes are shown below.

Generally, learning science is affected by students' language facility and in some cases, mathematics aptitude. Since science is taught in English, there are many cases where some of the terms are not understood well and the teacher needs to code switch. For concepts that are 
Table 9. 'Future Participation in Science' category: Mean values of items, category means and all-country means

Future Participation in Science

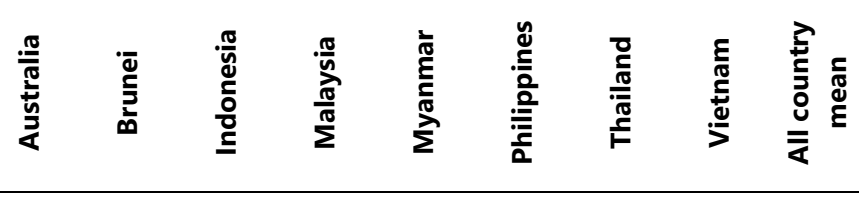

\begin{tabular}{llllllllll}
\hline I would like to study more science in the future. & 2.69 & 3.24 & 3.34 & 3.28 & 3.27 & 3.47 & 3.39 & 3.33 & $\mathbf{3 . 2 5}$ \\
\hline I would like to study science at university. & 2.48 & 3.14 & 3.15 & 3.25 & 3.15 & 3.36 & 3.16 & 3.21 & $\mathbf{3 . 1 1}$ \\
\hline I would like to work in a career involving science. & 2.41 & 3.02 & 2.97 & 3.06 & 2.94 & 3.14 & 3.04 & 3.09 & $\mathbf{2 . 9 6}$ \\
\hline Category mean & $\mathbf{2 . 5 3}$ & $\mathbf{3 . 1 3}$ & $\mathbf{3 . 1 5}$ & $\mathbf{3 . 2 0}$ & $\mathbf{3 . 1 2}$ & $\mathbf{3 . 3 2}$ & $\mathbf{3 . 2 0}$ & $\mathbf{3 . 2 1}$ & \\
\hline
\end{tabular}

developed using mathematical figures, some students who are not maths inclined tend to just ignore the teaching and eventually felt uninterested. (Philippines coordinator)

Students need to be provided with laboratory facilities to do science experiments by themselves. Lack of using computers and mobile technology in science teaching and learning is also another problem in schools. (Myanmar cordinator)

\section{FUTURE PARTICIPATION IN SCIENCE}

The students were asked about their intentions to study more science and if they would take up a science career in the future. As shown in Table 8, the all-country mean of 3.25 indicates that the vast majority of students from the eight countries would like to study more science in the future, including studying science at university (allcountry mean=3.11). However the proportion of students expressing the desire to work in a science-related career is smaller (all-country mean=2.96). At the individual country level, Australian students were least positive about future participation in science whereas students from the Philippines, Vietnam, Malaysia and Thailand were most positive about pursuing more science and taking up a science-based career (category means are 3.32, 3.21, 3.20 and 3.20 respectively).

In comparing students' interest in science (Table 7) and students' future participation in science (Table 9), it is interesting to note that Australia is the only country where the category mean value of 2.53 for Future Participation in Science is lower than its category mean value of 2.70 for Interest in Science. The reverse appears to be demonstrated for all the other SE Asian students where their country's category mean values for Future Participation in Science (see Table 9) are higher than their respective category mean values for Interest in Science (see Table 7). Hence interest in science does not necessarily translate to similar interest in future participation in science. For Australian students, there was more interest in science than in pursuing science further at university or taking up a science-related career. A possible reason for this is that Australia is more affluent and there are more career choices for the students while in developing countries, STEM-related careers offer better futures for the students.

\section{GENDER DIFFERENCES IN AFFECTIVE PERCEPTIONS OF SCIENCE LEARNING}

Table 10 shows differences in perceptions of girls and boys for the items investigated. There appears to be wide range of differences in the item perceptions of boys and girls from the different countries. The main findings in gender differences are summarised below:

- Where there are significant differences between the perceptions of boys and girls, the general trend is that boys are more positive than girls for most of the items.

- There was no significant differences for any of the items investigated between girls and boys from Thailand.

- Australian girls and boys showed significant differences in perception for more items than their peers in the SE Asian countries - 17 out of 39 items investigated showed significant differences, the majority of which were inclined more positively towards the boys.

- Girls in Brunei and Indonesia were more positive than boys in their countries for most of the items that showed significant differences e.g. 'I like to visit science centres and science museums', 'Students do experiments by following the instructions of the teacher' and a number of other items. With respect to 'I would like to work in a career involving science', Indonesian girls were more positive about this than Indonesian boys while the opposite is true of Australian and Vietnamese students i.e. the boys from these two countries were more positive about this item. There were no significant differences between boys and girls in Brunei, Malaysia, Myanmar, Philippines and Thailand for this item. 
Table 10. T-test results between genders for survey items that show significant differences at $p<0.01$ confidence level. Bold numbers indicate the more positive gender towards the item investigated

\begin{tabular}{|c|c|c|c|c|c|c|c|c|c|c|c|c|c|c|c|c|}
\hline \multirow[b]{2}{*}{ Relevance of science } & \multicolumn{2}{|c|}{ Australia } & \multicolumn{2}{|c|}{ Brunei } & \multicolumn{2}{|c|}{ Indonesia } & \multicolumn{2}{|c|}{ Malaysia } & \multicolumn{2}{|c|}{ Myanmar } & \multicolumn{2}{|c|}{ Philippines } & \multicolumn{2}{|c|}{ Thailand } & \multicolumn{2}{|c|}{ Vietnam } \\
\hline & Girls & Boys & Girls & Boys & Girls & Boys & Girls & Boys & Girls & Boys & Girls & Boys & Girls & Boys & Girls & Boys \\
\hline $\begin{array}{l}\text { Advances in science and technology usually } \\
\text { improve people's living standards. }\end{array}$ & 3.19 & 3.31 & & & & & & & & & & & & & & \\
\hline $\begin{array}{l}\text { Science helps me understand the things } \\
\text { around me. }\end{array}$ & & & 3.46 & 3.28 & & & & & & & & & & & & \\
\hline $\begin{array}{l}\text { Reasoning skills that are taught in science } \\
\text { classes can be helpful to me in my everyday } \\
\text { life. }\end{array}$ & 2.72 & 2.86 & & & 3.13 & 3.03 & & & & & & & & & & \\
\hline Science Outside School & Girls & Boys & Girls & Boys & Girls & Boys & Girls & Boys & Girls & Boys & Girls & Boys & Girls & Boys & Girls & Boys \\
\hline I like watching science programmes on TV. & 2.45 & 2.70 & & & & & & & & & 3.12 & 3.24 & & & 3.18 & 3.3 \\
\hline $\begin{array}{l}\text { I like to visit science centres and science } \\
\text { museums. }\end{array}$ & & & 3.18 & 3.01 & 2.97 & 2.74 & & & & & & & & & & \\
\hline $\begin{array}{l}\text { I would like to do more science activities } \\
\text { outside school, e.g. join a science club. }\end{array}$ & & & 3.15 & 2.89 & & & & & & & & & & & & \\
\hline $\begin{array}{l}\text { I like reading science magazines, books and } \\
\text { newspapers. }\end{array}$ & & & & & & & & & & & 3.02 & 3.07 & & & & \\
\hline $\begin{array}{l}\text { I like to visit web sites to learn about } \\
\text { science. }\end{array}$ & & & & & & & & & 2.93 & 3.13 & & & & & & \\
\hline Teaching and Learning Science & Girls & Boys & Girls & Boys & Girls & Boys & Girls & Boys & Girls & Boys & Girls & Boys & Girls & Boys & Girls & Boys \\
\hline $\begin{array}{l}\text { Students are given opportunities to explain } \\
\text { their ideas. }\end{array}$ & 2.63 & 2.77 & & & & & & & & & & & & & & \\
\hline $\begin{array}{l}\text { Students are required to design how a } \\
\text { science question could be investigated in } \\
\text { the laboratory. }\end{array}$ & 2.12 & 2.26 & & & & & & & & & & & & & & \\
\hline $\begin{array}{l}\text { Students are asked to apply a science } \\
\text { concept to everyday problems. }\end{array}$ & 2.15 & 2.31 & & & & & & & & & & & & & & \\
\hline $\begin{array}{l}\text { Students do experiments by following the } \\
\text { instructions of the teacher. }\end{array}$ & & & 3.43 & 3.31 & 3.28 & 3.18 & & & & & & & & & & \\
\hline $\begin{array}{l}\text { The teacher clearly explains the relevance of } \\
\text { science and technology concepts to our } \\
\text { lives. }\end{array}$ & 2.47 & 2.64 & & & 3.29 & 3.14 & & & & & & & & & & \\
\hline $\begin{array}{l}\text { The teacher tells stories about the lives of } \\
\text { scientists and how they make discoveries. }\end{array}$ & & & & & 3.16 & 3.04 & & & & & & & & & & \\
\hline $\begin{array}{l}\text { Students research online for information } \\
\text { related to the topic being studied. }\end{array}$ & 2.43 & 2.58 & & & 3.13 & 3.02 & & & & & & & & & & \\
\hline $\begin{array}{l}\text { Students are engaged in investigations } \\
\text { using online resources e.g. virtual } \\
\text { laboratory or simulations. }\end{array}$ & 2.00 & 2.17 & & & & & & & & & & & & & & \\
\hline $\begin{array}{l}\text { Students learn mostly from textbooks and } \\
\text { the teacher lectures. }\end{array}$ & & & & & 3.08 & 2.93 & 3.27 & 3.08 & & & & & & & 2.57 & 2.73 \\
\hline $\begin{array}{l}\text { Students learn interesting things in science } \\
\text { lessons. }\end{array}$ & 2.50 & 2.70 & 3.45 & 3.29 & & & & & & & & & & & & \\
\hline How Scientists Work & Girls & Boys & Girls & Boys & Girls & Boys & Girls & Boys & Girls & Boys & Girls & Boys & Girls & Boys & Girls & Boys \\
\hline $\begin{array}{l}\text { Scientists use different types of methods to } \\
\text { conduct scientific investigations. }\end{array}$ & & & 3.41 & 3.25 & & & & & & & & & & & & \\
\hline $\begin{array}{l}\text { All scientists follow the same step-by-step } \\
\text { scientific method. }\end{array}$ & & & & & & & & & 2.78 & 2.93 & & & & & & \\
\hline $\begin{array}{l}\text { Scientific investigations can be conducted } \\
\text { using computer technology. }\end{array}$ & & & & & 3.03 & 3.18 & & & & & & & & & & \\
\hline Scientific ideas can be changed. & & & & & 2.73 & 2.85 & & & & & & & & & 3.18 & 3.31 \\
\hline Interest in Science & Girls & Boys & Girls & Boys & Girls & Boys & Girls & Boys & Girls & Boys & Girls & Boys & Girls & Boys & Girls & Boys \\
\hline $\begin{array}{l}\text { I like science better than most other } \\
\text { subjects at school. }\end{array}$ & 2.07 & 2.41 & 2.47 & 2.69 & & & & & 2.95 & 3.13 & 2.73 & 2.88 & & & 2.66 & 2.82 \\
\hline Science is boring. (reversed) & 2.52 & 2.82 & & & & & & & & & & & & & & \\
\hline I enjoy acquiring new knowledge in science. & 2.95 & 3.14 & & & & & & & 3.33 & 3.44 & 3.48 & 3.63 & & & 3.36 & 3.46 \\
\hline I am interested in learning about science. & 2.89 & 3.08 & & & & & & & 3.27 & 3.39 & 3.47 & 3.58 & & & 3.21 & 3.33 \\
\hline Self-efficacy in Science & Girls & Boys & Girls & Boys & Girls & Boys & Girls & Boys & Girls & Boys & Girls & Boys & Girls & Boys & Girls & Boys \\
\hline I find science difficult (reversed) & 2.46 & 2.72 & & & & & 2.23 & 2.46 & & & 2.40 & 2.65 & & & & \\
\hline I learn science quickly & 2.38 & 2.75 & & & & & & & & & 2.75 & 2.93 & & & 2.61 & 2.82 \\
\hline Future Participation in Science & Girls & Boys & Girls & Boys & Girls & Boys & Girls & Boys & Girls & Boys & Girls & Boys & Girls & Boys & Girls & Boys \\
\hline I would like to study science at university. & & & & & & & & & & & & & & & 3.16 & 3.28 \\
\hline $\begin{array}{l}\text { I would like to work in a career involving } \\
\text { science. }\end{array}$ & 2.37 & 2.50 & & & 3.05 & 2.85 & & & & & & & & & 3.04 & 3.16 \\
\hline
\end{tabular}

- $\quad$ There are significant differences in perceptions between boys and girls in Australia, Brunei, Myanmar, Philippines and Vietnam for 'I like science better than most other subjects at school' and 'I enjoy acquiring new knowledge in science' with boys being more positive than girls. There are no significant gender differences in Indonesia, Malaysia and Thailand for these items. 


\section{DISCUSSION AND IMPLICATIONS}

The aim of the study was to investigate the affective domains of attitudes of Year 9 and 10 students towards a range of science-related categories pertaining to their valuing of science, their perception of how science is taught and how scientists work as well as their self-conception in science and future aspirations toward a science-related career. Investigating attitudes of Year 9/10 students is significant because these are the years that students make decisions in terms of their career choices and subjects to study. Wang and Degol (2013) indicated that the affective experiences and motivational beliefs individuals attach to specific subject areas (e.g. intrinsic interest in the subject, values attached to it) predict enrolment decisions. Understanding Year 9/10 students' attitudes towards science and science learning would help educators and policy makers plan curriculum and interventions that motivate students who are less positive about science/science learning as well as enhance the learning of students who are positive about science/its learning. This is to ensure that the composition of the STEM workforce meets the demand of every country. A comparative study across countries enable us to understand the social and cultural differences and contributing factors that lead to performance enhancement in science.

Eight Asia-Pacific countries participated in the project: Australia, Brunei, Indonesia, Malaysia, Myanmar, Philippines, Thailand and Vietnam. The findings show a general pattern where students from the SE Asian countries were generally much more positive across the categories of science/science learning explored than Australian students. The exception is the self-efficacy category where students from all the eight countries were less positive about their abilities than their interest and views of science generally. The findings concord with research that showed that the attitudes toward science from students in developing countries to be much more positive than those from economically developed countries (Awan et al., 2011; Freeman, 2014; Schreiner \& Sjoberg 2004; Sjoberg \& Schreiner, 2010). A possible reason for the more positive attitudes in developing countries is that science is perceived as one of the more important subject that provides the means of securing a brighter future career (as indicated by two of the country coordinators in the study). Being in a more affluent and gender-equal society with a high level of social security like Australia, the students, and in particular girls, have more choices and opportunities to pursue careers that reflect their interests and academic ability (Stoet \& Geary, 2018).

The study showed that students from across all countries perceived that the strategies and techniques used by teachers in the classrooms to be similar, with a mix of teacher-centred and student-centred approaches. Australian students were however, more negative in the category of 'Teaching and learning science' than their SE Asian peers, in particular their perceptions towards (insufficient) practical work and investigative work digitally.

Another pattern emerging from the study is that the category means for 'Interest in science' are higher than 'Self-efficacy in science' for all participating countries, indicating that (low) ability in science does not necessarily deter students' interest in science. Teachers should capitalise on this result to maintain students' interest at the same time implementing strategies to assist students to enhance their performance. One means of improving students' motivation and self-efficacy is integrated STEM. Studies have shown that integrating the STEM disciplines into students' learning such as through project-based learning motivates students and enhance performance (Hurley, 2001; Katehi, Pearson \& Feder, 2009; Stohlmann, Moore \& Roehrig, 2012; Tseng, Chang, Lou \& Chen, 2013).

The findings in the study indicate that the gender disparity in science is still strong across all the participating countries. Apart from Thailand where no significant differences between gender were demonstrated for all the items analysed, the general pattern for the other participating countries indicate that boys were predominantly more positive about the different aspects of science/science learning investigated. The findings concord with decades of findings that boys in general rated their classroom learning experiences more positively than girls (Gardner, 1974; Goodrum Hackling \& Rennie, 2001; Meyer, 1961; Schreiner \& Sjøberg, 2004). Studies have shown that it is not innate inability of girls to undertake STEM subjects/careers but rather other influencing factors such as stereotyping and parental/social influences (Prinsley, Beavis \& Clifford-Hordacre, 2016; Stoet \& Geary, 2018; Wang \& Degol, 2013). Strategies that eliminate stereotypes and bias, emphasise real-life STEM applications in teaching, provide role models and encourage a growth mindset will enhance girls' participation in science. There have also been a few successful experimental studies and small scale interventions that indicate that women's views of STEM disciplines are responsive to intervention techniques (Wang \& Degol, 2013).

\section{LIMITATIONS OF THE STUDY AND FURTHER RESEARCH}

One of the limitations of the study is the sampling of participants where randomness in school and participant selection is not uniform across the countries. Some country coordinators selected all high or medium or low SES schools and all high or low academically performing schools. Hence the samples may not be representative of the Year 9/10 student cohorts of each country and the results need to be used with caution. Nevertheless, the overall large sample sizes of the participants provide an initial snapshot of how the eight countries' students feel about science/science learning. 
Another limitation of the study is the reliability coefficients of a few items in the study are lower than less than .6 (Table 1), hence some aspects of the the results need to be interpreted with caution.

Further analysis of the data gathered in this research could be conducted as another study. This could include correlation studies and regression analysis that looks at variables that may be predictors of other variables, for example, looking for factors that might be predictors of wanting a career in science. These analyses are beyond the scope of the current study given the large amounts of data from eight countries. An alternate framework to guide correlation and regression studies will also be required.

Further research should include more in-depth studies in each country that include observations in science classrooms and interviews with students and teachers. As many schools in the participating countries are beginning to adopt STEM, research into the integrated aspect of these disciplines would inform educators whether the approach will engage more students and improve their self-efficacy that will lead to more uptake of STEM subjects and careers. More research is also required into girls' affective as well as cognitive attitudes towards STEM education is required, including comparative studies between the countries to elicit enablers and barriers in the different contexts and share successful strategies to lift women participation in STEM.

\section{ACKNOWLEDGEMENT}

The study was made possible by a number of people. Special thanks go to Dominador Dizon Mangao of SEAMEO-RECSAM for coordinating and liaising with the coordinators of participating countries. Special thanks also go to Dr Jennifer Fergusson for her analysis of the data in SPSS. Thank you to country coordinators Dr Lambas, Dr Nguyen Xuan Thanh, Joseph Gutierrez, Eakasit Piyasangtong, Kartini Rahim, Rizki Maisura and Kelvin Ledi for their assistance with gathering data from schools.

\section{REFERENCES}

Ainley, J., Kos, J., \& Nicholas, M. (2008). Participation in science, mathematics and technology in Australian education. ACER Research Monographs, 4. Victoria: ACER.

Ato, T., \& Wilkinson, W. J. (1983). Factors related to secondary school students' attitudes to science in Benue State of Nigeria. Research in Science $\mathcal{E}$ Technological Education, 1(2), 209-220. https://doi.org/10.1080/0263514830010209

Awan, R. U. N., Sarwar, M., Naz, A., \& Noreen, G. (2011). Attitudes toward science among school students of different nations: a review study. Journal of College Teaching and Learning, 8(2), 43-50. https:// doi.org/10.19030/tlc.v8i2.3555

Banu, D. P. (1986). Secondary school students' attitudes towards science. Research in Science E Technological Education, 4(2), 195-202. https:/ / doi.org/10.1080/0263514860040209

Barmby, P., Kind, P. M., \& Jones, K. (2008). Examining Changing Attitudes in Secondary School Science. International Journal of Science Education, 30(8), 1075-1093. https: / doi.org/10.1080/09500690701344966

Becker, K., \& Park, K. (2011). Effects of integrative approaches among science, technology, engineering, and mathematics (STEM) subjects on students' learning: A preliminary meta-analysis. Journal of STEM Education: Innovations \& Research, 12(5/6), 23-37.

Breakwell, G. M., \& Beardsell, S. (2016). Gender, parental and peer influences upon science attitudes and activities. Public Understanding of Science, 1(2), 183-197. https:/ / doi.org/10.1088/0963-6625/1/2/003

Brush, L. R. (1979). Avoidance of Science and Stereotypes of Scientists. Journal of Research in Science Teaching, 16(3), 237-41. https:// doi.org/10.1002/tea.3660160310

Butcher, H. J. (1969). An investigation of the 'swing from science'. Research in education, 1(1), 38-57. https:/ / doi.org/10.1177/003452376900100107

Cory, S. (2011). Driving Australia s economic future through robust investment in science and in science and maths education. Canberra: National Press Club Address.

Ebenezer, J. V., \& Zoller, U. (1993). Grade 10 students' perceptions of and attitudes toward science teaching and school science. Journal of research in science teaching, 30(2), 175-186. https:/ / doi.org/10.1002/ tea.3660300205

Education Council (2018). Optimising STEM industry-school partnerships: Inspiring Australia's next generation Final Report. South Carlton: Education Council.

Esser, F., \& Vliegenthart, R. (2017). Comparative research methods. In J. Matthes, C. Davis \& R. Potter (Eds), The International Encyclopedia of Communication Research Methods, pp 1-22. Wiley Online Library. https://doi.org/10.1002/9781118901731.iecrm0035 
Freeman, B. (2014). The Age of STEM: Science, technology, engineering and mathematics policy and practice globally. In Symposium on STEM education in Asia and the US, Indiana University Gateway-Tshinghua University Science Park, Beijing China, 21-22 October 2014. https:/ / doi.org/10.4324/9781315767512

Freeman, B., Marginson, S., \& Tytler, R. (2015). Widening and deepening the STEM effect. The Age of STEM: Educational policy and practice across the world in Science, Technology, Engineering and Mathematics, 1-21. https:// doi.org/10.4324/9781315767512

Gardner, P. L. (1974). Sex differences in achievement, attitudes, and personality of science students: A review. Research in Science Education, 4(1), 231-258. https:/ / doi.org/10.1007/BF02558596

Goodrum, D., Druhan, A., \& Abbs, J. (2012). The Status and Quality of Year 11 and 12 Science in Australian Schools: report prepared for the Office of the Chief Scientist. Retrieved from Canberra http://www.science.org.au/publications/documents/Year11and12Report.pdf

Goodrum, D., Hackling, M., \& Rennie, L. (2001). The status and quality of teaching and learning of science in Australian schools: A research report. Canberra: DETYA.

Haladyna, T., \& Thomas, G. (1979). The attitudes of elementary school children toward school and subject matters. The Journal of Experimental Education, 48(1), 18-23. https:/ / doi.org/10.1080/00220973.1979.11011707

Hurley, M. (2001). Reviewing integrated science and mathematics: The search for evidence and definitions from new perspectives. School Science and Mathematics, 101, 259-268. https://doi.org/10.1111/j.19498594.2001.tb18028.x

Jenkins, E., \& Nelson, N. W. (2005). Important but not for me: Students' attitudes toward secondary school science in England. Research in Science \& Technological Education, 23(1), 41-57. https://doi.org/10.1080/02635140500068435

Johnson, S. (1987). Gender differences in science: Parallels in interest, experience and performance. International Journal of Science Education, 9(4), 467-481. https:/ / doi.org/10.1080/0950069870090405

Jones, M. G., Howe, A., \& Rua, M. J. (2000). Gender differences in students' experiences, interests, and attitudes toward science and scientists. Science education, 84(2), 180-192. https://doi.org/10.1002/(SICI)1098237X(200003)84:2<180::AID-SCE3>3.0.CO;2-X

Katehi, L., Pearson, G., \& Feder, M. (Eds). (2009). National Academy of Engineering and National Research Council Engineering in K-12 education. Washington, DC: National Academies Press.

Kind, P., Jones, K., \& Barmby, P. (2007). Developing Attitudes towards Science Measures. International Journal of Science Education, 29(7), 871 - 893. https:/ / doi.org/10.1080/09500690600909091

Krapp, A., \& Prenzel, M. (2011). Research on interest in science: Theories, methods, and findings. International Journal of Science Education, 33(1), 27-50. https:/ / doi.org/10.1080/09500693.2010.518645

Liang, L., Chen, S., Chen, X., Kaya, O. N., Adams, A. D., Macklin, M., \& Ebenezer, J. (2006). Student Understanding of Science and Scientific Inquiry (SUSSI): Revision and Further Validation of an Assessment Instrument. Paper presented at the Annual Conference of the National Association for Research in Science Teaching (NARST), San Francisco, CA.

Logan, M. R., \& Skamp, K. R. (2013). The impact of teachers and their science teaching on students"science interest': A four-year study. International Journal of Science Education, 35(17), 2879-2904. https:/ / doi.org/10.1080/09500693.2012.667167

Lowery, L. F., Bowyer, J., \& Padilla, M. J. (1980). The science curriculum improvement study and student attitudes. Journal of Research in Science Teaching, 17, 327-335. https:/ / doi.org/10.1002/tea.3660170410

Lyons, T. (2006). Different countries, same science classes: Students' experiences of school science in their own words. International journal of science education, 28(6), 591-613. https:/ / doi.org/10.1080/09500690500339621

Lyons, T., \& Quinn, F. (2010). Choosing Science: Understanding the declines in senior high school science enrolments. Research Report to the Australian Science Teachers Association. Australia: University of New England.

Marsh, H. W., Trautwein, U., Lüdtke, O., Köller, O., \& Baumert, J. (2005). Academic self-concept, interest, grades, and standardized test scores: Reciprocal effects models of causal ordering. Child development, 76(2), 397-416. https:// doi.org/10.1111/j.1467-8624.2005.00853.x

Matthews, B., \& Davies, D. (1999). Changing Children's Images of Scientists: Can Teachers Make a Difference?. School Science Review, 80(293), 79-85.

McPherson, A. (1969). 'Swing from science'or retreat from reason?. Higher Education Quarterly, 24(1), 29-43. https:/ / doi.org/10.1111/j.1468-2273.1969.tb00316.x

Mead, M., \& Metraux, R. (1957). Image of the scientist among high-school students. Science, 126(3270), 384-390. https://doi.org/10.1126/science.126.3270.384 
Menis, J. (1983). Attitudes towards chemistry as compared with those towards mathematics, among tenth grade pupils (aged 15) in high level secondary schools in Israel. Research in Science E Technological Education, 1(2), 185-191. https:// doi.org/10.1080/0263514830010206

Meyer, G. R. (1961). Factors Accompanying the Scientific Interest of a Selected Group of English Secondary Pupils. Australian Journal of Education, 5(1), 27-40. https:/ / doi.org/10.1177/000494416100500105

Meyer, G. R. (1963). Factors related to scientific attitudes within the secondary schools of an Australian city. Australian journal of education, 7(1), 21-40. https:/ / doi.org/10.1177/000494416300700104

Osborne, J., Simon, S., \& Collins, S. (2003). Attitudes towards science: a review of the literature and its implications. International Journal of Science Education, 25(9), 1049-1079. https:/ / doi.org/10.1080/0950069032000032199

Potvin, P., \& Hasni, A. (2014). Interest, motivation and attitude towards science and technology at K-12 levels: a systematic review of 12 years of educational research. Studies in science education, 50(1), 85-129. https:/ / doi.org/10.1080/03057267.2014.881626

Powell, J. D. (1962). High school seniors' attitudes toward science. The bulletin of the National Association of Secondary School Principals, 46(277), 82-87. https:/ / doi.org/10.1177/019263656204627716

Schibeci, R. A., \& Riley, J. P. (1986). Influence of students' background and perceptions on science attitudes and achievement. Journal of Research in Science teaching, 23(3), 177-187. https:/ / doi.org/10.1002/ tea.3660230302

Schreiner, C., \& Sjøberg, S. (2004). ROSE: The relevance of science education. Sowing the seeds of ROSE. Background, Rationale, Questionnaire Development and Data Collection for ROSE (The Relevance of Science Education)-a comparative study of students' views of science and science education. Oslo: University of Oslo.

Shen, C., \& Tam, H.P. (2008) The paradoxical relationship between student achievement and self-perception: a cross-national analysis based on three waves of TIMSS data. Educational Research and Evaluation, 14(1), 87100. https:/ / doi.org/10.1080/13803610801896653

Silver, A., \& Rushton, B. S. (2008). Primary-school children's attitudes towards science, engineering and technology and their images of scientists and engineers. Education 3-13, 36(1), 51-67. https:/ / doi.org/10.1080/03004270701576786

Simpson, R. D., \& Oliver, J. S. (1985). Attitude toward science and achievement motivation profiles of male and female science students in grades six through ten. Science Education, 69(4), 511-525. https://doi.org/10.1002/sce.3730690407

Sjøberg, S., \& Schreiner, C. (2010). The ROSE project: An overview and key findings. Oslo: University of Oslo.

Stoet, G., \& Geary, D. C. (2018). The gender-equality paradox in science, technology, engineering, and mathematics education. Psychological science, 29(4), 581-593. https://doi.org/10.1177/0956797617741719

Stohlmann, M., Moore, T. J., \& Roehrig, G. H. (2012). Considerations for teaching integrated STEM education. Journal of Pre-College Engineering Education Research (J-PEER), 2(1), 4. https:// doi.org/10.5703/1288284314653

Tseng, K. H., Chang, C. C., Lou, S. J., \& Chen, W. P. (2013). Attitudes towards science, technology, engineering and mathematics (STEM) in a project-based learning (PjBL) environment. International Journal of Technology and Design Education, 23(1), 87-102. https:/ / doi.org/10.1007/s10798-011-9160-x

Tytler, R. (2007). Re-Imagining Science Education: Engaging Students in Science for Australia's Future. Australian Education Review 51. Victoria, Australia: Australian Council for Educational Research.

Wang, M. T., \& Degol, J. (2013). Motivational pathways to STEM career choices: Using expectancy-value perspective to understand individual and gender differences in STEM fields. Developmental Review, 33(4), 304-340. https:/ / doi.org/10.1016/j.dr.2013.08.001

Wooley, J. K. (1978). Factors Affecting Students' Attitudes and Achievement in an Astronomy Computer-Assisted Instruction Program. Journal of Research in Science Teaching, 15(2), 173-8. https://doi.org/10.1002/tea.3660150213

\section{http://www.ejmste.com}

